\title{
高中历史教学中如何培养人文精神的有效性
}

\author{
邓水清 \\ 江西省吉安市遂川县第二中学 \\ DOI:10.32629/jief.v2i7.1859
}

[摘 要] 一直以来, 人文精神教育都是高中阶段教育教学工作的重要内容, 在高中历史课程教学实践中渗透人文精神教育有助于学生树立正 确的价值观、世界观和人生观，促进学生良好品格的形成，对学生历史核心素养的全面发展有积极的影响。文章结合高中历史教学经验，探 讨了关于高中历史教学对学生人文精神的培养策略, 以供参考。

[关键词] 高中; 历史教学; 学生; 人文精神; 培养

中图分类号: G633.51 文献标识码: A

在我国古时的学术中就不断强调人文精神, 评价一个有才干的人都 是先看他待人处事方式及品格道德的, 由此可见历史本身就是人文学科, 因此在高中历史教学中来建立学生的人文精神成为学生成长的重要一 环, 我们可以从高中历史教学多个角度来促进学生的人文精神理论学习 与实践, 老师通过对学生实践的信息进行收集, 分析运用哪些方法有利 于高中教学人文精神的培养。

\section{1 人文精神及其在历史教学中的意义}

1.1 推动素质教育的全面实施

素质教育的宗旨是促进学生的身心健康的发展, 进而为社会的发展 培养人才。学生综合素质的提高是素质教育的重要内容, 因此, 教育过 程中学生是学习的主体, 教师要开发学生的智力, 运用多种方式激发出 学生各项能力, 培养学生良好的学习习惯, 提升学生的自主学习能力, 通过人文精神滋养学生的价值观念, 帮助学生塑造完整的理念, 促进学 生的人格发展。

对于高中学生来说, 历史学科的学习不仅有助于提高学生的人文精 神, 还可以实现素质教育的最终目标。教师要将人文精神培养的理念贯 穿教育的始终, 不断转变教学观念, 创新教学方法。历史学科的学习不 仅有利于学生综合素质的提高, 也有助于教学目标的实现。因此, 人文 精神的培养对高中学生素质教育的提高有着积极的促进作用。

1.2 有利于促进学生全面发展

近年来, 我国实行了新课改政策, 教育部门将学生人文精神的培养 以及综合素质的提高作为重要的改革内容。我国教育部推行了《基础教 育课程改革纲要 (试行)》, 这一纲要将新课改的目标进行了明确, 学生 创造力、实际操作能力、人文精神的提高以及环保意识的培养是重要的 改革内容。历史学科的课程改革与实际教学过程中也要贯彻落实这一改 革目标, 不仅要向学生传授历史知识, 还要培养学生的创造力以及逻辑 思维能力, 使学生自行探索科学的学习方法, 人文教育的开展要帮助学 生建立正确的价值观念, 探索人类生存与社会发展的意义之所在, 明确 人类、社会与自然三者间的内在关系。将人文精神的培养融入学生知识 体系的学习过程当中, 推动学生综合素质的提高。高中教育要促进学生 的全面发展, 为社会输送综合素质较高、价值观完善的专业性人才。

\section{2 在高中历史教学中培养人文精神的策略思考}

\section{1 全面提高教师的素质}

教师的知识讲解可以培养学生的人文精神, 教师的人文精神也会对 学生产生一定的影响, 因此, 教师要在新课改目标转变的大环境下不断 提升自身的综合素养, 同时也要改变以往过于重视知识传授的教学理念, 将人文精神的培养引入到历史学科的教学过程当中。

历史学科教学时, 教师不仅帮助学生学习历史知识, 还要培养学生 的自主学习能力, 帮助学习树立正确的价值观, 培养积极的生活态度。 教师要根据具体的教学内容制定详细的情感教育规划, 重视学生的课堂 学习效果, 了解学生对知识点的理解与吸收程度, 根据学生的差异制定 科学合理的教学规划。

同时, 教师要不断提升自身的综合素质，提升内在的人文素养，将
人文精神贯穿于学科教学的始终, 在教学过程中教师自身的行为与精神 可以对学生产生积极的影响作用。教师以关爱包容之心, 尊重学生个体, 以身作则规范学生的行为与习惯, 帮助学生树立正确的价值观念。

2.2 对各种材料进行综合性分析运用

教师要将历史教材进行分类整理, 深度挖掘其中蕴含的人文精神, 制定科学的教学规划, 培养学生的人文精神。教师在讲解历史人物时, 可以先让学生对人物进行自行评价, 分析历史事件的发展与结果, 探寻 成败的原因, 总结历史人物的特点, 深入理解历史人物与历史事件当中 所蕴含的人文精神。

通过学习历史, 学生可以接触到形形色色的历史人物, 认识到许多 拯救民族于危难的英雄人物, 学生可以从这些英雄人物的身上感受到不 同的人文精神, 通过学习大量历史资料, 学生的人文精神得以完善, 教 师要将不同人文精神进行深度剖析帮助学生更好地消化与理解。

教师还可以将情境教学法引入到历史学科的教育过程当中, 还原当 时的情境, 使学生如同身临其境, 深刻地理解历史发展进程, 同时还要 将历史教材的内容进行扩充与深化, 帮助学生深入挖掘其中所蕴含的人 文精神。在学习革命与战争一课时, 教师可以收集大量与战争相关的历 史资料, 学生可以对战争爆发的原因以及产生的影响进行深入的分析与 思考。

2.3 将历史教学与生活相联系

通过历史学科的学习, 学生可以将所学知识融入生活当中。然而现 阶段许多学校的历史教学脱离了生活的实际, 学生难以在生活当中良好 地应用与巩固, 教师对于历史学科对生活的重要性认识不足。因此, 历 史教师要培养学生关注生活, 将历史知识与生活实践相结合。

教师可以多带学生参观具有历史意义的场所, 阅读大量优秀的历史 相关图书与资料, 观看历史纪录片, 并根据时政新闻, 结合历史资料分 析时政, 帮助学生形成正确的时政观点, 促进学生历史知识的应用与巩 固, 将历史知识融入学生的生活当中。学生在历史知识的应用过程当中 可以深刻理解其中所蕴含的人文精神, 了解人文精神的价值之所在。

\section{3 结束语}

近年来, 我国推行了新课改政策, 各个学科都对自身的人文精神进 行了深入的挖掘与融合, 历史学科所蕴含的人文精神较为丰富, 因此对 学生人文精神的培养极为重要。通过历史学科的学习, 学生可以将历史 知识融入生活当中, 培养自身的人文精神理念, 通过思考形成自己独到 的见解, 总结出历史当中所蕴含的人文精神, 促进自身正确价值观的形 成, 使学生可以正确理解人类的存在价值, 正确看待人类与社会的关系。

\section{[参考文献]}

[1]徐丽华.探讨高中历史教学中如何培养学生的人文素养[J].中国 校外教育,2019(20):61+74.

[2]王云霞.高中历史教学中人文精神的培养研究 [J].中国农村教 育,2019(17):85

[3]李威威.新课标下高中历史课堂教学目标设计与落实的现状及建 议[D].河南大学,2019. 